\title{
OPPORTUNITY, OBLIGATION, RISK - THE REPRESENTATION OF PREIMPLANTATIONAL GENETIC TESTS IN THE HUNGARIAN ONLINE NEWS MEDIA
}

\author{
ESZTER KÁDÁR ${ }^{1}$
}

\begin{abstract}
Preimplantational genetic tests (PG tests) used in the processes of reproduction under laboratory conditions are considered to be one of the most controversial fields of gene technology. These tests are performed on embryos and result in the selection of the most capable embryo, while the rest are destroyed. Numerous moral questions arise regarding the ethical application of these procedures. This study investigated the representation of this topic in the Hungarian online media, applying (qualitative) Foucauldian discourse analysis. The results suggest that the narratives related to the topic can be organized according to their subjects around three discourses: those surrounding parents, those surrounding the embryo, and those surrounding the application of $P G$ tests. It was also revealed that narratives of risk, responsibility and the freedom of autonomous decisionmaking play an important role in constructing the representations of PG tests in the Hungarian online news media.
\end{abstract}

KEYWORDS: science communication, discourse analysis, reproductive technologies, human genetics, public understanding of science

\section{INTRODUCTION}

The development of reproductive technologies has made it possible for parents who long for the healthiest offspring to use selective reproductive technologies that involve the selection of embryos (Navratyil 2012). However, these procedures raise difficult ethical questions, such as what we consider to be the beginning of human life, what the appropriate conditions of selection are, where the boundaries of individual autonomy are, as well as whether society

\footnotetext{
1 Eszter Kádár is MA student at Humboldt Universität zu Berlin, e-mail: kadaresz@hu-berlin.de. The paper is based on the MA thesis of the author at Corvinus University, which was prepared as part of the OTKA/NKFIH 108981 research project. Head of research: Lilla Vicsek. Definition of applied medical terms may be find in the Appendix.
} 
has the right to define the criteria for a worthy life. Therefore it is particularly important to define the legal applicability of these technologies. Zoltán Navratyil refers to a series of international agreements that define the internationally recognized standpoint of embryonic research. At the same time, country-specific regulations may differ depending on whether autonomy, individual freedom, common good or the scientific assessment of advantages and disadvantages are of greater importance to legislators. Thus, this assessment also determines how the moral status of the embryo is perceived in the given society (Navratyil 2012).

The Human Reproductive Committee (HRB) ${ }^{2}$ lists the terms related to the application of selective reproductive technologies in Hungary. Parents who have a high risk of conceiving a child with a genetic disorder that is likely to significantly impair the child's life expectancy can choose to use preimplantational genetic diagnosis (PGD). In contrast, preimplantational genetic screening (PGS) does not target the diagnosis of rare, single-gene disorders but contributes to identify the risk of common diseases. Furthermore, the application of PGS in principle makes it possible to scan for desired characteristics such as hair color or sex. As a result, the committee claims that PGS is in the research phase and its routine use is not recommended.

Social scientists have been investigating the social aspects of the development of reproductive technologies for a long time. However, the critical sociological analysis of the moral considerations related to these technologies has been carried out in the Anglo-Saxon and Western European context so far, with few exceptions. These exceptions include qualitative research related to other types of biotechnology in Hungary. For example, Lilla Vicsek examined the media representation of stem cell research and public attitudes towards this topic (Vicsek 2011, Vicsek - Gergely 2011). Vicsek also examined the connection between media-constructed representations of biotechnologies and public attitudes related to the topic (Vicsek 2015). This research shows that the media do not emphatically represent moral issues related to gene technology topics. Zsófia Bauer's research analyzed the online forum discussions of patients who were involved in assisted reproductive processes. This study was one of the first pieces of sociological research in Hungary to examine the social implications of reproductive technologies. However, after analyzing the results the author concluded that the contributors to the observed online forums did not touch on ethical issues (Bauer 2013). Lilla Vicsek and Noémi Szolnoki analyzed interviews with women who took part in assisted reproductive procedures. The authors concluded their research with similar results to Bauer's (Vicsek -

2 For details about the ETT Human Reproductive Committee's position on Preimplantational genetic diagnosis and scans: http://www.ett.hu/hrb/pgd_pgs.pdf. (last opened: 2015. III. 25.). 
Szolnoki 2015). Thus, these results suggest that the ethical dimension regarding medical biotechnologies might be less prevalent in Hungary than in some other societies; for example, the UK and the US (e.g. Robertson 2003; Sadler - Zeidler 2004; Frewer et al. 1997; Frewer \& Shepherd 1995).

This study uses qualitative discourse analysis to investigate online press materials that interpret the topic of selective reproductive technologies. The focus is on online materials because little research interest has been dedicated to this emerging, increasingly commented on component of news media (Brossard 2013). Research that has sought to analyze the media representation of human genetics and reproductive technologies so far has mainly focused on print media (e.g. Brandenburg 2011, Condit et al. 1998, Conrad 2001, Hughes - Kitzinger 2008, Michelle 2007, Petersen 2001, Petersen 2005). First, we believe that through the analysis of online news media the knowledge base can be broadened in important ways. Second, we aim to take the first step towards exploring the Hungarian media image of PG tests.

Kellie Brandenburg's qualitative discourse analysis regarding Australian printed news media's interpretation of the topic of PGD served as the theoretical and methodological inspiration for this study. In Brandenburg's study, great attention was dedicated to the all-pervasive presence of risk. The author concludes that certain aspects of risk become outlined in discourses, such as the risk of free reproductive parental choice, the risk of naturally conceiving a child with gene-related disorders, as well as the risk of a dystopian, gene-engineered future through the application of selective reproductive technologies. Moreover, Brandenburg identified three groups of discourses according to the subject in focus. The author stresses that the identified groups of discourses are not separate from each other, but intersecting (Brandenburg 2011).

The identified groups were the following:

1. Discourses surrounding parents

2. Discourses surrounding children

3. Dystopia and critiques of PGD

With this study we aim to identify discourses that construct the image of selective reproductive technologies in the two most commonly read Hungarian online newspapers, as well as to compare the discourses identified by Brandenburg (2011) with the ones identified within the frames of this study. 


\section{THEORETICAL BACKGROUND}

\subsection{Media image}

New (gene) technological innovations such as PGD or PGS are increasingly raising ethical questions that the media interprets on the basis of scientific arguments and moral principles. Brigitte Nerlich et al. argue that the media often rely on pop cultural and literary references to aid understanding and communicate the ethical issues that arise in relation to the discourses. The selection and placement of metaphors is a conscious process as it underlines the complexity of the communicated message (Nerlich et al. 2003). In the media discourses, new discoveries about human genes are often referred to as part of a rapidly developing science that is bringing with it the risk of a eugenic future (e.g. Conrad 1999; Paul 1992; Petersen 2001; Nerlich et al. 2003; Hughes \& Kitzinger 2008).

Bogner \& Torgersen (2015) giving heed to Michel Foucault's theory of problematization, when identifying the characteristic forms of interpreting and legitimizing knowledge in the field of biotechnology. Foucault's notion of problematization can be defined as a process through which something becomes a phenomenon that previously was not perceived as coherent. Thus, problematization defines the way, how a given topic can be addressed in discourses (Foucault 1985 in Bogner \& Torgersen 2015). The findings of Bogner \& Torgersen (2015) show that biotechnology is not being problematized based on its objective properties but based on what is considered as a relevant issue related to it. These relevant issues were typically found to be moral issues, risks and economic aspects. Accordingly, the problematization of this topic affects the tools of interpretation in public debates therefore on the media platforms too.

Emma Hughes and Jenny Kitzinger found that in press articles dealing with human genetics or PG tests, so-called 'slippery slope' metaphors were often used. These metaphors suggest that scientists who apply these technologies are pushing "natural" limits and playing God. In the analyzed articles, the journalists tried to point out that the current use of human genetic technologies in the future might result in unforeseen, unintended and irreversible consequences. This dreadful future is often portrayed as the genetically engineered world pictured in Aldous Huxley's Brave New World, or in the popular movie Gattaca (Hughes \& Kitzinger 2008). However, Tania M. Bubela and Timothy A. Caulfield concluded that, in spite of the obvious presence of moral hazards, it is difficult to demonize these technologies since the media is more prone to emphasize 
the benefits of the innovations than their risks and disadvantages (Bubela and Caulfield 2004).

\subsection{Risk, autonomy, responsibility}

The moral issues related to the application of the technology are linked to the uncertainties regarding the technology's development, as well as to the risks of abuse, individual autonomy and responsibility. The central idea behind Ulrich Beck's Risk Society is that, as a result of modernity's development-oriented perspective in terms of socio-economic progress, we create unintended risks as side-products. Thus, modernization becomes reflexive (Beck 1992). Risks connected to PG tests are interpreted using multiple dimensions. First, the individual's real-time perceived personal health risks create uncertainty. While PG tests promise certainty in the future by eliminating uncertainties in the present (i.e. by detecting potentially emerging diseases in future), the application of these technologies opens up hitherto unimaginable, intergenerational health control opportunities. However, with the use of these technologies new uncertainties and moral issues both arise, together with dreadful prognoses regarding the future of humanity. Thus, as Anne Kerr and Sarah Cunningham-Burley (2000) also remark, PG tests embody the contradictions of reflexive modernity, as the application of PG tests imply the conflict of autonomy and responsibility taken..

In the present study, risk is defined based using Michel Foucault's constructivist approach. As opposed to Beck, Foucault emphasizes the risk and the power techniques of the state. Foucault claims that risk is not an objective, external entity, but can be understood as a dispositif that consists of various discourses, institutions, architectural forms, regulatory decisions, laws, administrative measures, scientific statements, philosophical, moral, and philanthropic propositions (Foucault 1980:194). Thus, the Foucauldian approach focuses on examining risk in relation to the political ethos of the neo-liberal state (Gabe et al. 2004). In Foucault's vision it is not possible to examine the given power techniques without taking the supporting political rationalities into account. Govern=government and mentalité $=$ modalities and variants of thought are power exercising techniques that exist in interaction and create governmentality. Governmentality refers to the power exercising techniques of the state that help to conduct and influence the conduct of citizens (Foucault 1991). Thomas Lemke states that in opposition to earlier times, the power exercising tools of the modern state are not only tools of direct intervention and coercion but also indirect exercises of power technologies, through which 
the state is capable of 'leading' its citizens without also taking responsibility for them. The neoliberal state defines individuals as responsible citizens, thus social risks such as diseases, disabilities, etc. are framed as and turned into individual risks. Accordingly, citizens of the neoliberal state base their decisions on perpetually making risk assessments across spheres of social existence (e.g. family life, professional life, etc.) (Lemke 2001). Carlos Novas and Niklas Rose claim that the perception of the body as genetic risk determines the selfdefinition of the individual. At the same time, the body-centered self-definition fits with the norms of advanced liberal societies that support entrepreneurship, self-actualization, and responsible behavior, which results in the pursuit of health and the intention of preventing future diseases (Novas and Rose 2000).

Several authors suggest (e.g. Bunton and Petersen, 2005; Brandenburg 2007) that it is worthwhile using the concept of governmentality as a tool to conduct a critical analysis of the representation of PG tests, since the governmentality concept helps to understand the impact of all-pervasive risk on the conflictual relationship between autonomy and responsibility. Following this advice, in this discourse analysis Foucault's governmentality concept was adopted and applied as a methodological tool.

\section{DATA AND METHOD}

\subsection{Data}

Helene Starks and Susan Brown Trinidad (2007) state that the most commonly used qualitative approaches in health research are phenomenology, discourse analysis and grounded theory. While phenomenology focuses on how people make sense of their own experiences, grounded theory is used to develop explanatory theories of social phenomena (Starks and Trinidad 2007). In the research described in this paper qualitative discourse analysis was performed. This method was considered the most appropriate as we wanted to understand how language is used in the process of making sense of PG tests. As source materials, the archives of the two most frequently read Hungarian online newspapers were used. Based on the database ${ }^{3}$ of ite.hu, the two most often read online news sites in Hungary were origo. $h u^{4}$ and index. $h u^{5}$. The creators

\footnotetext{
3 Source: http://ite.hu/legnezettebb-hazai-weboldalak-rangsora/

4 daily visitor: 579213

5 daily visitor: 492072
}

CORVINUS JOURNAL OF SOCIOLOGY AND SOCIAL POLICY VOL. 8 (2017) 1 
of the database compiled their list based on the available public databases of web-audit suppliers such as Gemius-Ipsos. The list contains the hundred most visited websites averaged on January 2014. In the first step of the analysis, a keyword search was performed in order to define the composition of the sample. The keywords applied were the following expressions, in Hungarian: "preimplantational", "reproductive", "test-tube baby, "test-tube process", "assisted reproduction", and "gene test". In order to be included in the sample, PG tests also had to be mentioned - this was discerned by reading through the texts. The search was not limited in time, being performed from the year of launch of each site (origo.hu: 1998, index.hu: 1999) until March 2015. A total of 59 articles were analyzed, of which 38 pieces were from origo.hu and 21 from index. $h u$ or from the thematic blogs related to these online newspapers, whose content was also archived. Tamás Bodoky argues that among leading Hungarian news portals, origo.hu and index.hu - similarly to the printed press - can be defined as mass media, hence the theoretical framework of mass media can be applied to them (Bodoky 2005). In accordance with this, the online news media sources were considered to be standard forms of press.

\subsection{Method}

Discourse analysis was carried out based on the genealogical discourse analyses performed by Jane Carabine (2001). Following Carabine's example, the concept of "normalization" developed by Michel Foucault was applied (Carabine 2001). As Foucault states, normalized conduct is also defined through the branding of abnormalities (Foucault 1977). Therefore it was assumed that the discourses determined the group of normalized, accepted PG tests, as well as the recognized behavior of actors involved in the procedures (patients, clinics, and specialists). In the first step of the analysis, repeated, in-depth reading of the articles was undertaken. The original linear structure of the texts was disrupted and the selected parts were reorganized along a newly developed logical structure. Similarly to Brandenburg's analysis (2011), the topicrelated statements were grouped based on their subjects. Taking Carabine's methodological recommendation into account, the data was interpreted using category-assigned terms. Thus, the hidden content of the texts was revealed. Additionally, the discursive construction of the actors taking part in PG tests was examined (Carabine 2001). Similarly to Brandenburg's analysis (2011), actors (including journalists) were recognized as participants who also take part in the construction of the media discourses. Keeping in mind a recommendation 
from Nerlich et al. (2003), special attention was dedicated to the discursive application of science-fiction metaphors and similes. Following the guidelines of Carabine (2001), gaps surrounding the representation of the topic were detected.

\section{RESULTS}

The results of this research reveal that in the period under review, the discourses of the analyzed media show similarities to the discourses of the Australian print media (Brandenburg 2011). The groups of discourses that Brandenburg identified are dominant in the Hungarian sample as well, although the discursive strategies that construct the discourses of the analyzed Hungarian online news portals show some remarkable differences. Therefore, we adopted Brandenburg's grouping, while giving heed to reveal the country-specific/unique discursive strategies and narratives. However, as a result of the technological development in the years following Brandeburg's study, in addition to PGD, other selective reproductive procedures, such as PGS or mitochondrial DNA test6 are also in use. Therefore, the concerns and critics related to the use of these new procedures are also part of the online media discourses.

Thus, we identified three groups of discourses that occasionally overlap with each other:

1. Discourse surrounding parents

2. Discourse surrounding the embryo

3. Discourse surrounding the application of PG tests

6 The mitochondrial DNA test is considered to be a relatively new technology. HRB Comittee describes the technology as a procedure that enables during the IVF the exchange of the fertilized egg's mitochondia and thus a small part of the DNA too. The intervention does not affect the nuclear DNA that forms the majority of the genome. It also does not modify the mitochondrial DNA, but replaces it entirely with another, stem from ,another mother”. It is known that the majority of the genome is found in the nuclear DNA. However, the mitochondria's seemingly insignificantly small DNA also have improtant qualities. Their flaws cause rare but severe congenital diseases (ETT, HRB, 2015c, pp. 1). According to the Comittee's statement, the technology's risks are dwarfed by it's offered benefits. Therefore the mitochondrial DNA test is proved to be a promising therapeutic option (ETT, HRB, 2015c, p. 2). 


\subsection{Discourses surrounding parents}

Texts that referred to parents or patients as their subjects were grouped into category one [1], and through which discursive strategies are the representations of parents, patients or women constructed was examined. The construction of parents - similarly to Brandenburg's analytical process (2011) - was grasped through the discourses of responsibility, as well as free, autonomous decision making and its limits. Parents using PG tests were portrayed as people with health risks.

"My father suffered from a severe bleeding disorder, hemophilia A. This was found out when I was a little girl. A blood test revealed that I myself carry gene variants responsible for causing the disorder. This means that if I give birth to a boy, he will be at high risk of being sick as well."?

The parents' self-definition as a health risk affects their reproductive decisions. Thus, parents were often portrayed as actors who - through responsible choices - resort to all accessible means of decreasing intergenerational, inherited health risks and maximizing the health of their future offspring. This responsible choice is expressed through the application of PG tests.

“... The 27-year-old mother got her ovaries checked because in her husband's family many women had breast cancer. The same method was used [PGD] in her case as with the IVF program as concerns implanting the fertilized egg into the uterus. With this test the risk of certain genetic diseases such as cystic fibrosis is lessened."

The analyzed Hungarian online media judged the PG tests based on their efficiency; in particular, the degree to which they enabled the identification of disability. Parental autonomy - similarly to Brandenburg's findings (2011) - was found to be observable in the responsible acts of parents. To avoid giving birth to a child with a disease, parents used PG tests. In the discourses, this decision was interpreted as the easier and more ethical decision compared to abortion in a later period of pregnancy.

\footnotetext{
7 Pesthy, G.: Instead of popular practices, embryo screening to filter hemophilia; origo.hu, 2010. November 24., http://bit.ly/1MuJsJu (last opened: 2015. XI. 08.)

8 Independent News Agency: Baby was born free from breast cancer risks in Great Britain; index.hu, 2009. January 09., http://bit.ly/1NEzfLE (last opened 2015. XI. 08)
} 
"The process [PGD] is beneficial because examining the embryo is less risky than examining the fetus. If any abnormality is found, then the parent does not have to terminate the pregnancy."

Similar to Brandenburg's findings (2011), PG tests were interpreted in the discourses of the analyzed articles as market services. Using the term 'service' refers to freedom of choice. It also involves the handling of embryo as a market good, since it implies that using PG tests makes it possible to 'buy' an embryo with the best genetic characteristics.

"It has been also suggested that in the future those who can financially afford it will be able to select among their offspring, and only the best ones or only the ones with desired external characteristics will be chosen." ${ }^{\prime 10}$

The legal terms for applying PG tests are strictly defined, and currently these technologies may only be used to diagnose genetic diseases. However the narrative that emphasized the importance of restricting parental autonomy was significant. The narrative of the inherent risk of free parental decisions often highlighted the danger that parents would take advantage of the opportunities offered by the technology. Accordingly, in the future parents would be able to select a perfect successor in terms of a range of characteristics.

"With the new method inherited diseases could be prevented. Nevertheless, critics say parents would rather opt to choose hair color."

At the same time, an opposing narrative was also present in the analyzed articles. In particular, index.hu promoted the concept of unlimited parental autonomy. According to this narrative, parental autonomy serves societal interests such as population growth. Generally, the advantages of PG tests were stressed more than the hazards. However, this narrative - unlike the Australian study results (Brandenburg 2011) - appeared to be isolated, weak, and unable to promote public discussion on the topic. The emphasis on free parental choice

9 Origo: Sick embryos are being filtered out; origo.hu, 2012. July .28. http://bit.ly/1La5ETX (last opened: 2015. XI. 11.)

10 Fessler, Emma: Will they really create superhumans in the future?; life.hu, 2012. September .04. http://bit.ly/1Y4o0Pq (last opened: 2015.XI.11.)

11 Strovecz, Adrián: The latest steps in baby-design: Preview of the child; origo.hu, 2014. April 10. http://bit.ly/1koYrdS (last opened: 2015. XI. 11.) 
in the discourses may lead to the indirect discrimination of people living with disorders or illnesses diagnosed by PG tests. In the analyzed sample, parents using PG tests to transmit their own disabilities were constructed as norm-breakers. This is also suggested by the following quote that defines the appropriate use of PG tests, and suggests deviant ways of applying it too:

"The preliminary genetic examination of test-tube babies has been developed in order to reduce the number (tens of thousands) of disabled children born each year." 12

In narratives interpreting the issue of disability transmission, parents living with disabilities were not constructed as decision makers with a strong group identity who sought to reject the accepted health norms of society. Unlike parents in some other countries, Hungarian parents with disabilities do not see their otherness as a means of identity construction, but as an obstacle. Therefore, their disabilities influence their reproductive choices. Parental responsibility is depicted in these cases as parental decisions that increase the chance of conceiving a child whose characteristics match the dominant healthrelated norms.

\subsection{Discourses surrounding the embryo}

Texts interpreting the embryo were classified into group two [2]. These were examined through investigating which discursive strategies constructed the representations of the embryo.

Similarly to Brandenburg's results (2011), discourses surrounding the embryo were found to be constructed in the analyzed sample through narratives that expressed the passivity of the embryo. Embryos were often referred to as objects of examination, abnormalities, risk carriers and complications. However, this passivity implied a certain ambivalence regarding the Hungarian sample. This ambivalence stems from the unclear moral status of the embryo which was discernable through the parallel use of a duality of approaches. As Brandenburg states, the embryo is on the one hand the object of parental responsibility and PG tests, but on the other also gains subjectivity through these (Brandenburg 2011). This duality was also present in the analyzed sample. Typically, the expressions

12 MTI: Transmissible disability, index.hu, 2006. October 03. http://bit.ly/1PoFvIL (last opened: 2015. XI. 11.) 
"embryo", "fetus" and "already born children" were used interchangeably in the articles regarding the subject:

“... The first healthy newborns for whom the entire genome of the oocytes had been screened were recently born."13

In the quotation above, the genetic testing of the already born child is referred to. As the quote is about children already born, it may be beyond dispute that the use of the relative pronoun "who" is valid. However, the question of the embryo's subjectivity during the PG tests is left unclear.

Framing the narrative using the abnormal-normal duality to interpret the status of the embryo was a frequent motif in the Australian sample (Brandenburg 2011). Similarly, in this study "a healthy child is born" was a very common phrase that appeared in the titles or in the main texts of the analyzed articles. At the same time, underlining that the child was born healthy can be seen as a kind of implicit dichotomy (the desirable, healthy offspring is contrasted with a risky and abnormal one). Thus, PG tests are a guarantee of healthy offspring, according to this narrative.

Selection and decision are of great importance when interpreting the discourses surrounding the embryo. Indeed, selection raises several moral issues. It was expected that, similarly to the Australian print media, the two most-read Hungarian news portals would reflect upon these issues. In contrast, strong expressions of opinion were rarely found in the analyzed samples. In the period under analysis the articles on the two most often read news sites consistently neglected the moral issues relating to totipotency ${ }^{14}$. The following quote is an example of the dominant narrative that focuses on the health of the implanted embryo or the already born child (stressing that cell removal does not cause disorders), without reflecting upon the ethical issues related to the fate of the unused embryos. The neglect of ethical issues was also an element of the pragmatic narrative that focused on the effectiveness of the technology. However, the analyzed articles typically highlighted only one aspect of risk: the health risks of the unborn child. Future risks created by the use of PG tests, such as the risk of reproductive parental decisions, or the future risks of abusing the technology (eugenics, genetic engineering, issues concerning the fate of unused embryos) were not stressed to an equal extent:

13 MTI: First healthy test-tube babies to undergo complete genetic testing have been born; origo.hu, 2010. December 5., http://bit.ly/1MAnZyZ (last opened: 2015. XI. 11.).

14 Totipotency refers to a condition in which the embryo can develop into a viable human body. When the pre-implantation genetic tests are performed, each of the tested embryos are totipotent. Thus, considering the criterion for viability that determines the status of the embryos, they must be considered humans (Navratyil 2012). 
"So-called pre-implantational diagnosis is a new approach in the field of gene diagnostics. The essence of this is that every cell of the eight-cell human embryo has the ability to create a whole human body (this is called totipotency), thus removing one cell does not cause birth defects"15

The motif 'outside of the body' is of particular importance in the discourses surrounding the embryo. The sharp distinction between the laboratory and the intrauterine processes implies that inception of pregnancy is calculated from implantation. Based on the fact that the cited article argued that the sampling did not affect the further development of the embryos, we can conclude that the unselected embryos were not yet seen as living creatures. In addition, the perception of the status of the selected and non-selected embryo was also different in the discourses surrounding the embryo. The embryo was retroactively given the moral status of a human when it had developed into a healthy child.

"We got back a five-day-old girl embryo who was finally born healthy. All the inconveniences of the test-tube programs are dwarfed for those who want a healthy child, and this is possible with this method."16

The analyzed sample in the examined period was characterized by inconsistent use of terminology. The articles often did not sharply distinguish between the fetus and the embryo. Consequently, PG tests were also mentioned among prenatal (in-utero) tests. However, lack of this distinction leads to the neglect of ethical issues, risks and uncertainties related to PG tests.

"In Hungary, fetal examinations such as PGS: a-CHG are not used, but other prenatal diagnostic methods are available. These include the conventional fetal karyotyping, fluorescent and real-time PCR, fluorescence in situ hybridization (FISH), a variety of isotopic studies and the above-mentioned preimplantational genetic diagnosis (PGD)." ${ }^{\prime 17}$

In Brandenburg's study the contrast between naturally conceived children and those ones who had undergone gene tests - as part of in-vitro fertilization - was a common element of discourses surrounding the embryo. This oppositional

15 Dr. Boldogkői, Zsolt: The fetus can already be tested using the mother's blood; origo.hu, 2013. January 2., http://bit.ly/1Y4qcqg (last opened: 2015. XI. 11.).

16 Pesthy, Gábor: Instead of popular practices, embryo screening to filter hemophilia; origo.hu, 2010. November 24., http://bit.ly/1MuJsJu (last opened: 2015. XI. 08.)

17 Illyés, András: Fetal genetic tests: new opportunities and threats; origo.hu, 2010. October 28., http://bit.ly/1WMCnLk (last opened: 2015. XI. 11.). 
stance emphasized the unnaturalness of the PG tested embryo (Brandenburg 2011). This strict distinction was present in the sample of the Hungarian online media as well. In addition, the articles also differentiated between so-called "donor babies" and "designer babies" according to the purpose of the test. Donor babies were associated with positive terms such as giving, donating, helping and curing. ${ }^{18}$ Thus, PG tests gained legitimation when the fact of donation was emphasized. Furthermore, donor babies were often characterized as those who were born in order to save another life, but not according to their own rights. Expressions like "test-tube sibling" and "savior sibling" were very often used in the analyzed sample. This suggests that, according to the donor baby narrative, the newborn gains subjectivity through a sibling. However, and in contrast with the donor baby concept, the designer baby was associated with negative connotations such as artificiality, engineering and abnormality. As a result, the oddity and otherness of the PG tested newborns were stressed in the discourses. This artificiality was often associated with mass production. These associations, through different discursive strategies - similarly to Brandenburg's (2011) findings -, constructed the embryo as a commodity on the market (e.g.: "Smart babies are produced in China" 19 , "I'll take a boy around 3500 grams" These narratives stressed the immorality of commodification through absurd exaggerations.

The selection of the donor embryo raises ethical questions that the discourses of Hungarian media - in contrast to Australian ones - treated at a distance. It was typical of the dominant narrative of the discourses that they mostly covered news related to PG tests from Western Europe and the USA. The news sites treated the moral risks of PG tests primarily as the subject of public debate outside Hungary. The Hungarian context remained unreflected on, although such procedures have been used in that country. It was typical of the analyzed articles that they debated the moral risks of the procedures, but concentrated on current events and set aside the authors' critical stance. Articles dealing with the international scientific breakthroughs primarily referred to the legal conditions and limitations of application in Hungary. Moreover, in the analyzed articles the fact that moral issues related to PG tests could be the subject of public debate did not emerge.

18 MTI: An infant cures with their umbilical cord blood; index.hu, 2009. March 13. http://bit. ly/1PoHa13 (last opened: 2015. XI. 11.).

19 Molnár, Orsolya: Smart babies are produced in China; origo.hu 2013. March 23., http://bit. ly/1SiDT11 (last opened: 2015. XI. 11.).

20 Velvet: Third child on order; velvet.hu, 2005. July 19., http://bit.ly/1lkccuA (last opened: 2015. XI. 11.). 


\subsection{Discourse variations}

Discourses that focused on views about the application of PG tests were grouped under category three [3]. These were examined through investigating which discursive strategies constructed the representations of these technologies.

The results of this study show - similarly to the results of an examination of Australian print media (Brandenburg 2011) - that the dominant discourse in news coverage portrayed PGD as a source of risk, preying upon humanity's future. These risks were constructed as a vision of a dystopian genetically engineered future created by the abuse of PGD. This narrative was argued on an abstract level and involved fears for the future of humanity. Typical of this discursive strategy was the use of pop cultural and science-fiction references, as well as slippery slope metaphors. This emphasizes the results of Hughes and Kitzinger who found that these references shape the media representation of human genetics (Hughes and Kitzinger 2008).

"One of China's largest biotechnology companies is conducting research on thousands of people to identify the genetic background of intelligence. Many people fear that due to these results Pandora's Box will be opened and the selection of smartest embryos in artificial insemination programs will begin [...] The studies could lead to genetic manipulation over time (genetic engineering) as well. Andrew Nicol's sci-fi movie from 1997 (The Gattaca) was based on a similar concept."21

In contrast to the critical narrative, a supportive narrative that emphasized the current and practical advantages of PGD was also present. In discourses surrounding PGD, the technology was described as a milestone in preventative medicine. It was often emphasized that PGD, compared to prenatal tests, is less invasive and safer since the health of the newborn child is not at risk:

"An embryo biopsy does not adversely affect the health of newborn PGDchildren. It is important to let parents know that the PGD method is safe." 22

Personal interest stories play a significant role in the construction of the supportive narrative. In these stories the advantages of PGD are emphasized

21 Molnár, Orsolya: Smart babies are produced in China; origo.hu, 2013. March 23., http://bit. ly/1SiDT11 (last opened: 2015. XI. 11.).

22 MTI: Genetic screening of embryos is safe; index.hu, 2012. July 4. http://bit.ly/1O3yZUE (last opened: 2015. XI. 11.). 
through underlining the personal benefits obtained by patients who use PGD as a part of assisted reproduction. This contributes to the normalization and acceptation of the technology. Similarly to Brandenburg's findings, there is an epistemic divide between the supportive and critical narrative. Personal interest stories link the application of PGD to concrete and sorrowful personal experiences. These stories stress the rationality of patients in choosing PGD and thereby establish a supportive narrative, building upon the reader's empathy. In contrast, the critical narrative judged the conduct of patients using PGD on behalf of the interests of mankind. However, this abstract level of social responsibility was lacking the motif of compassion.

The construction of PGS had many similarities to the construction of PGD. Besides the dystopian narrative, the construction of PGS as an effective technology which may be able to increase the number of births was also dominant. PGS was constructed in the reports as a novelty compared to PGD, and a well less normalized technology, which raised more doubt. Nik Brown has described the phenomenon of "hype" around innovation. This hype indicates that expectations and uncertainties associated with new technologies have a strong impact on the construction of discourse (Brown 2003).

"Numerous researchers agree that the new method has great potential, but they are also concerned that it is still too early. One reason for this is that genetic tests may reveal deviations that can be difficult to interpret correctly, which could trigger unnecessary worries in parents." ${ }^{23}$

The construction of the PGS narrative regarding the Hungarian context was mainly defined by articles which interpreted the practices of a specific private reproductive institute in Budapest. The risks of PGS in this narrative were not constructed with reference to often-cited moral risks - such as the threat of a dystopian, gene-engineered future -, but as concrete and tangible present-time financial risks. PGS was very often referred to in the articles as an unethical practice of the clinic. This reference rather referred to the supposedly deficient information provided to patients, and the ignorance of HRB recommendations regarding PGS than moral issues related to the technology:

"Infertile couples who might have been waiting for years to have children can easily think that they will do whatever it takes to finally have a child. However, if they need to spend their money on examinations that impair

23 Illyés, András: Fetal genetic tests: new opportunities and threats; origo.hu, 2010. October 28., http://bit.ly/1WMCnLk (last opened: 2015. XI. 11.). 
their chances and they are not even informed about the experimental nature of the procedure, the term 'scam' mentioned in the title of the article may actually be accurate for describing this practice." 24

In discourses focusing on the Hungarian context, the interpretation of uncertainties related to PGS were channeled into a pragmatic, efficiency-driven narrative. Thus, most critics of the application of PGS sought to emphasize the unproven efficiency of this new technology.

\section{CONCLUSION}

Findings of the study described in this paper show that the discourses of the two most frequently read Hungarian online news sites around PG tests could be grouped according to their subjects - similarly to the results of the Australian study (Brandenburg 2011). These subjects were identified as parents, embryos and PG tests. Although the subjects of the discourses were found to be identical in the Australian and Hungarian samples, some major differences could be identified regarding the discursive strategies.

Lemke claims that, due to the advances in gene technology, the genome no longer represents ready-made destiny that is outside personal control. On the contrary, genetic tests are based on the logic of prevention and anticipation. Therefore their utilization by the individual has exploitable potential (Lemke 2004). Thus, if we accept that in neoliberal societies the state indirectly exercises power over technologies, we can also conclude that the state's regulatory competence is expressed through the responsible choices of rational individuals. In this regard, the definition of parents as autonomous, rational decision-makers suggests that responsible citizens take action to preserve their own and their family's health and minimize the risks of developing a disease now or in the future. Accordingly, the results of the present research show that, in the discourses of the analyzed news sites, parents were constructed as potential objects of health risk who regulated their conduct in order to reduce these potential risks.

The embryo was constructed as a hybrid subject in the discourses whose status could be interpreted in a complex way. On the analyzed news sites its representation was constructed as the object of parental responsibility and

24 Origo: The In-Vitro Association passes criticism on the reproductive clinic's practice; origo.hu, 2013. September 23., http://bit.ly/1Y4rp0M (last opened: 2015. XI. 8.). 
PG tests. However, moral status could change according to the results of the embryo's 'performance' on a PG test. The chosen embryo was constructed as an entity endowed with the subjectivity of a potentially healthy child, and the non-chosen embryo as complication that could be eliminated through rational parental choice (the use of a PG test). The status perception of the embryo changed according to the aim of the procedure that was applied. When the purpose of the PG test was to help the already born but sick child, the embryo's construction as a 'donor baby' gained positive meaning and was interpreted through phrases like "helper" or "savior". In contrast, the construction of a 'designer baby' was strongly connected to genetic engineering. With the term 'design' the narrative aimed to emphasize the PG test's dehumanizing and abnormal nature. Thus, in interpreting the concept of designer baby the embryo is constructed as the symbol of society's teleological, future-oriented perspective, and expresses human society's desire for perfection.

As part of this study, besides the construction of PGD, the construction of other selective reproductive procedures - such as PGS - were examined. Regarding the analyzed sample I conclude that the discourses surrounding PG tests were characterized by a lack of timeliness and information compared to the results of Australian research. The Hungarian online news media typically lacked critical reflection about ethical issues related to PG tests. Besides a critical, dystopian narrative, a pragmatic approach defined significantly the discourses of the Hungarian online media. In this pragmatic interpretation, the most important element was the commencement of a successful pregnancy. Therefore the ethical issues surrounding embryo selection did not represent a critical feature of narratives supporting or criticizing the application of PG tests in Hungary. It was observable that the discourses of the articles dealt with moral issues on an abstract level. The articles reviewed and summarized the arguments of critical groups, but opinion regarding these issues was not expressed. Similar to Brandenburg's research findings (2011), the fault-line between supportive and critical narratives was defined by an epistemic divide. Supportive narratives aimed to normalize the technology through telling concrete personal stories (e.g. about family tragedies), while the critical narratives relegated the issue to an abstract level. These narratives constructed the technology as a potential threat to the future of humanity. Paradoxically, these narratives lacked compassion on an individual level. Thus, the reflexive modern problematic embodied by PGD was identified through the presence of the two opposing and dominant narratives (Kerr and Cunningham-Burley 2000). 
A wide range of Hungarian online news articles deal with the problems that are raised in relation to the use of PGS. One of the reasons for this is that a Hungarian private human reproduction institute has started to use this form of technology, although the legal conditions for its application were antinomic. In addition, there was no prior public discussion about the topic in Hungary. Moreover, the news coverage of the clinic's unique practices allowed special insight into the competitiveness of actors on the Hungarian reproductive market. It would therefore be worthwhile revealing the narratives of different actors such as lawyers, doctors, patients and psychologists in terms of various epistemological positions in a further study.

\section{REFERENCES}

Bauer, Zsófia (2013), "Bound together by Fate and Faith. A Qualitative Analysis of Online Discussions on Assisted Reproduction in Hungary", Proceedings of FIKUSZ '13 Symposium for Young Researchers, 2013. http://kgk.uni-obuda. hu/sites/default/files/09_Bauer_Zsofia.pdf (last opened: 2015. III. 21.)

Beck, Ulrich (1992), Risk Society: Towards a New Modernity (Vol. 17). Thousand Oaks, CA, Sage.

Bodoky, Tamás (2005), "A hírportál, mint tömegmédium”, Médiakutató, nyár, pp. 67-82.

Bogner, Alexander -Torgersen, Helge (2015), "Different ways of problematising biotechnology governance", Public Understanding of Science, vol. 24, no. 5, pp. 516-532.

Brandenburg, Kellie (2007), “A New Sociological Imperative: Towards Engaging with Preimplantation Genetic Diagnosis", Health Sociology Review, vol. 16, no. 1, pp. 79-88.

Brandenburg, Kellie (2011), "Risk, parental autonomy and the epistemic divide: preimplantation genetic diagnosis in the Australian print news media, 19902007", New Genetics and Society, vol. 30, no. 1, pp. 115-131.

Brossard, Dominique (2013), "New media landscapes and the science information consumer", Proceedings of the National Academy of Sciences, vol. 110, no. 3, pp. 14096-14101.

Brown, Nik (2003), "Hope against hype: accountability in biopasts, presents and futures", Science Studies, vol. 16, no. 2, pp. 3-21.

Bubela, Tania M. - Caulfield, Timothy. A. (2004), "Do the print media "hype" genetic research? A comparison of newspaper stories and peer-reviewed research papers", Canadian Medical Association Journal, vol. 170, no.9, pp. 1399-1407. 
Bunton, Robin - Petersen, Alan (2005), "Genetics and governance? An introduction“, In: Bunton, Robert - Petersen, Alan, ed., Genetic Governance. Health, Risk and Ethics in the Biotech Era, New York, Routledge, pp. 1-26.

Carabine, Jean (2001), "Unmarried Motherhood 1830-1990: A Genealogical Analysis," in: Wetherell, Margaret - Taylor, Stephanie - Yates, Simeon, J., ed., Discourse as Data: A Guide for Analysis, Thousand Oaks, CA: Sage, pp. 267-310.

Condit, Celeste M. - Ofulue, Nneka - Sheedy, Kristine M. (1998), "Determinism and mass-media portrayals of genetics", The American Journal of Human Genetics, vol. 62, no. 4, pp. 979-984.

Conrad, Peter (2001), "Genetic Optimism: Framing Genes and Mental Illness in the News", Culture, Medicine and Psychiatry, vol. 25, no. 2, pp. 225-247.

ETT, HRB. (2015c). Az ETT Elnökségének és Humán Reprodukciós Bizottságának (HRB) állásfoglalása a "háromszülős embrió" mesterséges elóállításával kapcsolatban. http://www.ett.hu/alltaj/haromszulos allf_201503.pdf. (last opened: 2015.03.25.)

Foucault, Michel (1977), "Discipline and punish: The birth of the prison", Vintage

Foucault, Michel (1980) “'The Confessions of the Flesh'”, in Colin Gordon, ed., Power/Knowledge. Selected Interviews and \& Other Writings 1972-1977, Pantheon Books, pp.194-228.

Foucault, Michel (1991), "Governmentality", in: Burchell, Graham - Gordon, Colin - Miller, Peter, ed., The Foucault Effect: Studies in Governmentality, University of Chicago Press, pp. 87-104.

Gabe, Jonathan - Bury, Mike - Elston, Mary Ann (2004), Key Concepts in Medical Sociology, London, Sage.

Frewer, Lynn J. - Shepherd, Richard (1995), "Ethical concerns and risk perceptions associated with different applications of genetic engineering: Interrelationships with the perceived need for regulation of the technology", Agriculture and Human Values", Agriculture and Human Values, vol. 12, no.1, pp. 48-57.

Frewer, Lynn J. - Howard, Chaya - Shepherd, Richard (1997), "Public concerns in the United Kingdom about general and specific applications of genetic engineering: Risk, benefit, and ethics", Science, Technology \& Human Values, vol. 22, no. 1, pp. 98-124.

Hughes, Emma - Kitzinger, Jenny (2008), "Science fiction fears? An analysis of how people use fiction in discussing risk and emerging science and technology", SCARR Working Paper. http://www0.caerdydd.ac.uk/jomec/ resources/SciFiFearsWP28.pdf (last opened: 2015. I. 19.) 
Kerr, Anne - Cunningham-Burley, Sarah (2000), "On Ambivalence and Risk: Reflexive Modernity and the New Human Genetics", Sociology, vol. 34, no. 2, pp. 283-304.

Lemke, Thomas (2001), "The birth of bio-politics": Michel Foucault's lecture at the Collège de France on neo-liberal governmentality", Economy and Society, vol. 30, no. 2, pp. 190-207.

Lemke, Thomas (2004), "Disposition and determinism - genetic diagnostics in risk society", The Sociological Review, vol. 52, no. 4, pp. 550-566.

Michelle, Carolyn (2007), "Human clones talk about their lives': media representations of assisted reproductive and biogenetic technologies", Media, Culture \& Society, vol. 29, no. 4, pp. 639-663.

Navratyil, Zoltán (2012), A varázsló eltöri pálcáját? A jogi szabályozás vonulata az asszisztált humán reprodukciótól a klónozásig, Budapest, Gondolat Kiadói Kör Kft.

Nerlich, Brigitte - Johnson, Susanne - Clarke, David D. (2003), "THE FIRST "DESIGNER BABY": The Role of Narratives, Cliche's and Metaphors in the Year 2000 Media Debate", Science as Culture, vol. 12, no. 4, pp. 471-498.

Novas, Carlos - Rose, Nikolas (2000), "Genetic risk and the birth of the somatic individual", Economy and Society, vol. 29, no.4, pp. 485-513.

Paul, Diane B. (1992), "Eugenie Anxieties, Social Realities, and Political Choices", Social Research, vol. 59, no. 3, pp. 663-683.

Petersen, Alan (2001), "Biofantasies: genetics and medicine in the print news media", Social Science \& Medicine, vol. 52, no. 8, pp. 1255-1268.

Petersen, Alan (2005), "The metaphors of risk: Biotechnology in the news", Health, Risk \& Society, vol. 7, no. 3, pp. 203-208.

Robertson, John A. (2003), "Extending preimplantation genetic diagnosis: the ethical debate Ethical issues in new uses of preimplantation genetic diagnosis", Human Reproduction, vol. 18, no.3, pp. 465-471.

Sadler, Tory D. - Zeidler, Dana L. (2004), "The morality of socioscientific issues: Construal and resolution of genetic engineering dilemmas", Science Education, vol. 88, no. 1, pp. 4-27.

Starks, Helene - Trinidad, Susan Brown (2007), "Choose your method: A comparison of phenomenology, discourse analysis, and grounded theory", Qualitative health research, vol. 17, no. 10, pp. 1372-1380.

Vicsek Lilla (2011), "Costs and benefits of stem cell research and treatment: media presentation and audience understanding in Hungary", Science Communication, vol. 33, no. 3, pp. 309-340.

Vicsek, Lilla - Gergely, Júlia (2011), "Media presentation and public understanding of stem cells and stem cell research in Hungary", New Genetics and Society, vol. 30 no. 1, pp. 1-26. 
Vicsek, Lilla - Bauer, Zsófia (2012), "Biotechnológiai kockázatok és előnyök a médiában és a közönség körében: össejtkutatás és össejtkezelések", Médiakutató, ősz, pp. 131-143.

Vicsek, Lilla (2013), ““'Gene-fouled or gene-improved?” Media framing of GM crops and food in Hungary", New Genetics and Society, vol. 32, no. 1, pp. 54-77.

Vicsek, Lilla (2015), “Kapcsolódások a biotechnológiai nyilvánosság színterei között", Médiakutató, tavasz, pp. 91-106.

Vicsek, Lilla - Szolnoki, Noémi (2016), “Az embrió, mint társadalmi-kulturális entitás: Az embriók konstruálása a lombik bébi eljárásban résztvevő magyar páciensek körében.“ in: Kisdi, Barbara ed., Létkérdések a születés körül. Társadalomtudományi vizsgálatok a szülés és születés témakörében, Budapest, L'Harmattan, pp. 150-167.

\section{APPENDIX}

\section{Definition of applied medical terms}

Assisted Reproductive Technologies: "All treatment or procedures that include the handling of both human oocytes and sperm or embryos, for the purpose of establishing pregnancy. These includes but not limited to in-vitro fertilization and embryo transfer [...]" (Zegers-Hochschild et al. 2009)

Selective Reproductive Technologies: In-vitro fertilization procedures that involve the selection of a certain pre-embryo to implant in order to avoid the birth of a child with severe diseases and life-shortening disabilities (Wilkinson and Garrard 2013).

Preimplantational Genetic Diagnosis: a selective reproductive procedure that aims to diagnose rare genetic (monogenic, chromosomal) abnormalities before the implantation of the pre-embryo. It is applied on individuals with high risks to conceive a child with genetic illnesses that significantly impair life expectancy (ETT, HRB 2015).

Preimplantational Genetic Scan: a selective reproductive procedure that aims to enhance the success of the in-vitro fertilization in general by detecting genetic mutations, chromosomal aneuploidies that in random incidence may lead to the destruction of the embryo (ETT, HRB 2015). 


\section{Sources}

ETT, HRB. (2015), "Preimplantációs Genetikai Diagnózis és Szürés ETT Humán Reprodukciós Bizottság állásfoglalása,", http://www.ett.hu/hrb/pgd_ pgs.pdf. (last opened: 2016.09.21.)

Wilkinson, Stephen - Garrard, Eve (2013), "Eugenics and the Ethichs of Selective Reroduction", Keele University

Zegers-Hochschild, F. - Adamson, G. D. - Mouzon, J. de - Ishihara, O. - Mansour, R. - Nygren, K., Sullivan, E. - Poel, S. van der. (2009), "The International Committee for Monitoring Assisted Reproductive Technology (ICMART) and the World Health Organization (WHO) Revised Glossary on ART Terminology, 2009.” Human Reproduction, dep343.

\section{Further resources}

http://www.origo.hu/hir-archivum/index.html http://index.hu/24ora?main:tech 